\title{
Supply Chain Finance
}


Other titles in Foundations and Trends ${ }^{\circledR}$ in Technology, Information and Operations Management

Designing Effective Supply Chains in Strategic Alignment with Demand Characteristics and Market Requirements

Mojtaba Mahdavi and Tava Lennon Olsen

ISBN: 978-1-68083-268-6

Last-mile Supply Network Distribution in Omnichannel Retailing: A Configuration-Based Typology

Stanley Frederick W. T. Lim, Elliot Rabinovich, Dale S. Rogers, and Timothy M. Laseter

ISBN: 978-1-68083-184-9

Performance Improvement in Health Care Organizations Hummy Song and Anita Tucker

ISBN: 978-1-68083-192-4

Integrated Modeling for Location Analysis

Ho-Yin Mak and Zuo-Jun Max Shen

ISBN: 978-1-68083-190-0 


\title{
Supply Chain Finance
}

\author{
Edited by \\ Panos Kouvelis \\ Olin Business School \\ Washington University in St. Louis, USA \\ kouvelis@wustl.edu \\ Ling Dong \\ Olin Business School \\ Washington University in St. Louis, USA \\ dong@wustl.edu \\ Danko Turcic \\ Olin Business School \\ Washington University in St. Louis, USA \\ turcic@wustl.edu
}




\title{
Foundations and Trends $^{\circledR}$ in Technology, Informa- tion and Operations Management
}

\author{
Published, sold and distributed by: \\ now Publishers Inc. \\ PO Box 1024 \\ Hanover, MA 02339 \\ United States \\ Tel. +1-781-985-4510 \\ www.nowpublishers.com \\ sales@nowpublishers.com \\ Outside North America: \\ now Publishers Inc. \\ PO Box 179 \\ 2600 AD Delft \\ The Netherlands \\ Tel. +31-6-51115274
}

The content of the book was originally published in Foundations and Trends ${ }^{\circledR}$ in Technology, Information and Operations Management, vol. 10, nos. 3-4.

ISBN: 978-1-68083-377-5

(C) 2017 Now Publishers Inc

\begin{abstract}
All rights reserved. No part of this publication may be reproduced, stored in a retrieval system, or transmitted in any form or by any means, mechanical, photocopying, recording or otherwise, without prior written permission of the publishers.

Photocopying. In the USA: This journal is registered at the Copyright Clearance Center, Inc., 222 Rosewood Drive, Danvers, MA 01923. Authorization to photocopy items for internal or personal use, or the internal or personal use of specific clients, is granted by now Publishers Inc for users registered with the Copyright Clearance Center (CCC). The 'services' for users can be found on the internet at: www.copyright.com

For those organizations that have been granted a photocopy license, a separate system of payment has been arranged. Authorization does not extend to other kinds of copying, such as that for general distribution, for advertising or promotional purposes, for creating new collective works, or for resale. In the rest of the world: Permission to photocopy must be obtained from the copyright owner. Please apply to now Publishers Inc., PO Box 1024, Hanover, MA 02339, USA; Tel. +1 781871 0245; www.nowpublishers.com; sales@nowpublishers.com

now Publishers Inc. has an exclusive license to publish this material worldwide. Permission to use this content must be obtained from the copyright license holder. Please apply to now Publishers, PO Box 179, 2600 AD Delft, The Netherlands, www.nowpublishers.com; e-mail: sales@nowpublishers.com
\end{abstract}




\title{
Foundations and Trends ${ }^{\circledR}$ in Technology, Information and Operations Management \\ Volume 10, Issue 3-4, 2017 \\ Editorial Board
}

\author{
Editor-in-Chief \\ Charles Corbett \\ UCLA, Anderson School of Management \\ United States
}

\section{Editors}

Fernando Bernstein

Duke University

Cheryl Gaimon

Georgia Institute of Technology

Uday Karmarkar

University of California, Los Angeles

Sunder Kekre

Carnegie Mellon University

Panos Kouvelis

Washington University

Michael Lapré

Vanderbilt University

Karl Ulrich

University of Pennsylvania

Luk van Wassenhove

INSEAD 


\section{Editorial Scope}

\section{Topics}

Foundations and Trends ${ }^{\circledR}$ in Technology, Information and Operations Management publishes survey and tutorial articles in the following topics:

- B2B Commerce

- Business Process Engineering and Design

- Business Process Outsourcing

- Capacity Planning

- Competitive Operations

- Contracting in Supply Chains

- E-Commerce and E-Business Models

- Electronic markets, auctions and exchanges

- Enterprise Management Systems

- Facility Location

- Information Chain Structure and Competition

- International Operations

- Marketing/Manufacturing Interfaces

- Multi-location inventory theory
- New Product \& Service Design

- Queuing Networks

- Reverse Logistics

- Service Logistics and Product Support

- Supply Chain Management

- Technology Management and Strategy

- Technology, Information and Operations in:

- Automotive Industries

- Electronics manufacturing

- Financial Services

- Health Care

- Media and Entertainment

- Process Industries

- Retailing

- Telecommunications

\section{Information for Librarians}

Foundations and Trends ${ }^{\circledR}$ in Technology, Information and Operations Management, 2017, Volume 10, 4 issues. ISSN paper version 1571-9545. ISSN online version 1571-9553. Also available as a combined paper and online subscription. 


\section{Contents}

Supply Chain Finance: Overview and Future Directions

P. Kouvelis, L. Dong and D. Turcic

Part 1: Supplier Financing

Agency Cost of Debt: A Case for Supplier Financing

J. Chod

Trade credit as an option to acquire financing

P.-Y. Brunet, V. Babich, and T. Aouam

Impact of Trade Credit Financing on Firm Performance in Supply Chains

H.-H. Lee, J. Zhou, and J. Wang

Part 2: Buyer Financing

Reverse factoring: A theory on the value of payment terms extension

S. D. Lekkakos and A. Serrano 
Improving Channel Efficiency through Financial Guarantees by Large Supply Chain Participants

T. I. Tunca and W. Zhu

Purchase Order Finance: A Conceptual Model with Economic Insights

F. Tanrisever and M. van Bergen, and M. Reindorp

Part 3: Inventory Models and Financing Considerations

Managing Inventory for a Multidivisional Firm with Cash Pooling119 K. Shang, J. Wang, And Y. Yang

On the Cost of Capital in Inventory Models

A. Serrano

Part 4: Operational Investments and Financing Issues

Debt Financing and Supply Chain Capacity Investment Q. $\mathrm{Hu}$

Production, Capacity, and Liquidity of a Self-Financed Firm 168 J. Ning

Supply Chain Debt Financing in Competition

Q. Hu and P. Su

Crowdfunding via Revenue-Sharing Contracts

S. Fatehi and M. R. Wagner 


\section{Supply Chain Finance: Overview and Future Directions}

The following volume, which surveys the most recent research in supply chain finance, is motivated by the success of the third "Supply Chain Finance \& Risk Management Workshop," which was held at the Olin Business School of Washington University in St. Louis, on May 14-15, 2017. The workshop was organized in collaboration and with the financial support of the Boeing Center for Supply Chain Innovation (BCSCI) at Washington University. During the workshop, the participants wondered if it would be possible to establish an outlet that would give them a timelier access to the latest research on supply chain finance and supply chain risk management. (It is well-known, that due to review process lead times, articles that eventually make it into one of our top journals are typically 2 to 3 years old.) The idea of producing an edited volume, which would include an overview of the latest articles on the topics above appealed not only to the workshop participants but also to other active members of the iFORM (Interface of Finance, Operations, and Risk Management) research community. The Editor of "Foundations and Trends in Technology, Information and Operations Management," published by Now Publishers Inc., Professor Charles Corbett was open to the idea and accepted our proposal to produce two volumes. The first volume is on the topic of supply chain finance and the second is on the subject of integrated risk management. 
The editors extended an invitation to 90 or so top researchers from the iFORM community who have participated in at least one of the supply chain finance and risk management workshops and who have seminal contributions in these areas. In response, the editors received 30 or so submissions. Following a careful review process, 21 manuscripts were eventually accepted for publication. The volume on supply chain finance includes 12 of the 21 papers, which are organized into four parts; the remaining articles, which are included in the volume on supply chain risk management, are organized in three parts.

\section{Overview of the Supply Chain Finance Area}

Supply chains are complex ecosystems consisting of all parties, directly and indirectly, involved in delivering goods and services to end customers. The health of a supply chain is dependent on the coordination of physical, information, and financial flows facilitating the value-adding activities performed by members of the supply chain. Earlier supply chain management practices had focused on improving the efficiency of physical flows and increasing information sharing across organization boundaries. Innovative practices such as Continuous Replenishment, Quick Response, Vendor Management Inventory, Collaborative Planning, Forecasting, and Replenishment have found applications in various industries. While working capital has always been critical to every business, supply chain professionals' active engagement in coordinating financing and supply chain took off only in the last decade, partly due to the increasing globalization of the economy, the scarcity of capital in the wake of 2008 financial crisis, and the maturing of technology (Herath, 2015).

To understand the importance of coordinating financial decisions and value-creation decisions of firms, let us return to the ModiglianiMiller Theorem. The Modigliani-Miller Theorem and the follow-up theorems state that the total market value of the firm (which is the sum of the market value of its debt and equity) is independent of its capital structure and its dividend policy (Modigliani and Miller, 1958; Miller and Modigliani, 1961). The Modigliani-Miller Theorem implies that a firm's capital structure is irrelevant to its operations decisions, which 
aim at increasing the value of the firm. The assumptions underpinning the irrelevancy theorem are: frictionless markets (no transaction costs); competitive markets (individuals and firms are price takers); individuals and firms can undertake financial transactions at the same prices; information symmetry; no taxes; a firm's cash flows do not depend on its financing policy (e.g., no bankruptcy costs).

However, the real world is full of evidence that those assumptions do not hold. Taxations, transaction fees associated with financing, decisions based on maximizing managers' self-interest (agency issue), insider knowledge (information asymmetry), possibilities of costly bankruptcy and financial distress are issues that businesses encounter daily. Because of those observations, the Modigliani-Miller Theorem provides a framework that allows us to focus on factors that are important determinants of the optimal capital structure and the relevance of finding the joint optimal operational and financing decisions.

Supply Chain Finance (SCF) focus is on creating liquidity in the supply chain through various Buyer or Seller-led solutions with or without a facilitating technology. The role of SCF is to optimize both the availability and cost of capital within a given buyer-supplier supply chain. To add further value, information on the physical flow of goods can be monitored. The coupling of information enables lenders to mitigate financial risk within the supply chain. The mitigation of risk allows more capital to be raised, capital to be accessed sooner, or capital to be raised at lower rates (Global Business Intelligence, 2016). Supply chain participants reside in diverse economic environments, are of different sizes, face a variety of uncertainties, have different bargaining powers over its trading partners, and have different accessibilities to capital markets. Many forms of financing arrangements between buyers and suppliers have emerged intending to overcome challenges in their specific economic and business environments.

Supplier-based finance, also known as trade credit, is a common financing scheme that has existed for a long time. Under this financing scheme, an upstream supplier allows the downstream buyer to postpone payment to a date after the invoice date. Empirical studies have documented prevalent practices of trade credit in many industries, between 
suppliers and buyers of various sizes. Finance theories have offered explanations for the advantages of trade credit over bank financing, e.g., price discrimination, transaction costs, enforcing repayment, salvaging inventory, asymmetric information, moral hazards, etc. Those studies tend to overlook the tradeoffs involved in making operational decisions, such as coping with demand uncertainty, retail price, product assortment, production technologies, and the associated strategic interactions between suppliers and buyers. This is where supply chain researchers can contribute to better understanding of the rationale and motivation of supplier based finance in the context of the supply chain. (Part 1 of this volume is dedicated to the study of supplier based finance.)

Globalization of supply chains has given opportunities to suppliers in developing economies to become supply chain partners of large, global companies. The emergence of e-commerce platforms has provided opportunities for entrepreneurs to reach end customers. Suppliers in developing economies and small- and medium-sized suppliers in developed economies all face challenges in accessing capital markets. Innovative financing schemes, often initiated by large, creditworthy buyers, have emerged to address those challenges. Examples of such include reverse factoring and purchase order financing. What specific challenges a financing scheme intends to address and what impacts they have on operational decisions and supply chain performance are important questions need to be addressed. (Part 2 of this volume is dedicated to the study of buyer based finance.)

Examining operational investment decisions through the lens of recognizing the interconnection of operations and financing decisions can generate new insights into those investment decisions. For example, inventory holds up capital. A firm's inventory investment decision can significantly affect its cash flows, and its ability to invest in other projects or its dividend policies. A manufacturer's capacity investment decision determines its ability to negotiate with downstream buyers and to meet uncertain market demand. How are capacity investments funded and how contractual arrangements are made between the manufacturer and the buyer determine the level of capacity commitment and the manufacturer's exposure to bankruptcy risk. (Chapters 3 and 4 of this 
volume are dedicated to the study of inventory and other operations investment decisions with financial considerations.)

\section{Part 1: Supplier Financing}

There are three papers included that discuss supplier based financing issues. The papers explore different issues: motivation and rationale for supplier based financing, the optimal mix of bank financing and supplier financing, and empirical study of the impact of trade credit on firm performance. We briefly comment on their contributions in this introduction.

The first paper in this part (Part 1: Supplier Financing) is by Jiri Chod on "Agency Cost of Debt: A Case for Supplier Financing", and it discusses agency issues in the presence of supply chain finance. The paper first discusses how debt financing distorts the inventory decisions of a multi-product newsvendor-like retail firm. Relative to the firm's first-best stocking levels (i.e., when you maximize the total value of the firm, both equity and debt), a bank financed firm favors products of lower salvage value, higher profit margin, or the ones representing a larger proportion of total inventory. Under trade credit financing, with some assumptions, the firm chooses the first best inventory levels. The two important assumptions are: suppliers are competitive (price takers and offer credit terms to break even on expectation), and the retailer buys the multiple items from the same supplier. The paper also discusses pure supplier financing versus mixed bank-supplier financing, and under what conditions mixed financing is preferable. It also outlines some future research directions, with most of them dealing with the implications of removing the assumptions of the current analysis. This work nicely adds to a recent literature in interfaces of operations and finance that considers agency issues between the firm's insiders and outside investors, and it indicates that supplier financing might be able to mitigate some of these issues in certain cases.

The second paper is by Pierre-Yves Brunet, Vlad Babich, and Tarik Aouam on "Trade Credit as an option to acquire financing". It is a paper that offers another motivating rationale for the use of trade credit and the value it creates. The paper models a cash constrained manufacturer 
facing uncertain demand and with access to bank financing and trade credit. Banks set loan limits that reflect the borrowers' repayment histories. Trade credit financing enables the manufacturing firm to build credit history and improve access to bank financing in future periods. The paper nicely adds to a vast literature on motivating rationale for trade credit practices and their impact on both the finance and the operations literature.

The third paper is by Hsiao-Hui Lee, Jianer Zhou, and Jingqi Wang on the "Impact of Trade Credit Financing on Firm Performance in Supply Chains". This is an interesting empirical study of the impact of trade credit financing on firm performance in supply chains. It decomposes trade credit financing into two parts: an industry average trade credit level representing common practices and an abnormal component measuring deviation from industry practices. While average trade credit benefits both parties involved (supplier and buyer), abnormal trade credits are plausibly driven by competition in the industry and could be associated with poor buyer performance. The paper is a nice complement to previous analytical studies on the topic of supplier financing in supply chains.

\section{Part 2: Buyer Financing}

There are three papers included in our edited volume that discuss buyer based financing issues in supply chains. Buyer based financing refers to various practices where large creditworthy buyers (often) work together with banks to provide innovative financing programs to help small and medium-sized enterprises to gain easier access to capital market. The three papers in this part discuss the rationales of different types of buyer based financing arrangements and their impacts on supply chain performance. We briefly comment on their contributions.

The first paper in this part (Part 2: Buyer Financing) is by Spyros Lekkakos and Alejandro Serrano on "Reverse Factoring: A Theory on the Value of Payment Term Extensions". It presents a model providing rationale for the use of reverse factoring practices in the presence of extended payment terms by buyers. Their results support the argument that such practices can facilitate higher investment levels by the buyer, 
and they can lead to increased benefits for the integrated supply chain.

The second paper is by Tunay Tunca and Weiming Zhu on "Improving Channel Efficiency through Financial Guarantees by Large Supply Chain Participants". The paper models and provides insights on Buyer Intermediated Financing (BIF) (some form of reverse factoring motivated by business practices rather common in China). It offers support on why these practices might reduce wholesale prices, increase order fill rates, and create a win-win situation for both buyers and suppliers.

The third paper is by Fehmi Tanrisever, Matthijs van Bergen, and Matthew Reindorp on "Purchase Oder Finance: A Conceptual Model with Economic Insights". The paper is a conceptual model explaining the value proposition of Purchase Order Finance and some of the current practices. Purchase Order Finance is a short term commercial financing option that provides a firm with capital to pay its suppliers, given the existence of a purchase order from a final customer. The paper offers the economic rationale and some insights on conditions that favor the application of Purchase Order Finance.

\section{Part 3: Inventory Models and Financing Considerations}

There are two papers that discuss inventory models with explicit financial considerations. Cost of capital is an important component in the inventory cost calculation. The two papers in this part of the special issue explore how to coordinate the management of the cash flow and inventory flow within an organization and the relationship between a firm's inventory policy and its cost of capital.

The first paper in this part (Part 3: Inventory Models and Financing Considerations) is by Kevin Shang, Jianan Wang and Yi Yang on "Managing Inventory for a Multidivisional Firm with Cash Pooling".This presents a model for joint inventory replenishment and cash retention policy for a firm with multiple business divisions and a centralized cash pool. It describes the problem formulation, and a near optimal heuristic for its solution. It offers insights on the value of cash pooling for multi-divisional firms.

The second paper is by Alejandro Serrano on "On the Cost of Capital in Inventory Models: The Case of Deterministic Demand". The paper 
studies the correct cost of capital that should be assigned to inventory purchases. The author finds that a rate close to the risk-free rate should be used to value inventory-related investments when the inventory cost function is dominated by holding cost.

\section{Part 4: Operational Investments and Financing Issues}

There are four papers that address operational investments with explicit financing considerations.

The first paper in this part (Part 4: Operational Investments and Financing Issues) is by Joice Hu on "Debt Financing and Supply Chain Capacity Investment". The paper studies a supply chain composed of a supplier and a buyer. The supplier has to make a buyer-specific capacity investment before demand uncertainty has been resolved. After the uncertainty has been resolved, the firms decide whether or not to trade with each other. The authors show that a supplier who pays for its investment with risky loans ends up committing to a higher initial capacity that an equity-financed supplier. Moreover, the capacity with borrowing (equity) will be higher (lower) than the channel-efficient capacity.

The second paper is by Jie Ning on "Production, Capacity, and Liquidity of a Self-Financed Firm". The paper formulates a dynamic model of integrated decisions on capacity investment (or disinvestment), production (with flexibility in choosing among facilities and products to produce), and cash management (with some of the cash used for issuing dividends). Each period the firm faces stochastic market prices and investment yields, and chooses how much to produce, invest in capacity expansion, distribute as a dividend, and retain as liquidity. The firm's objective is to maximize the expected present value of dividends. The main results include a decomposition of the value function for the dynamic problem, which simplifies the computation of the optimal policy and the value function. The decomposition allows the author to make a real interpretation of the optimal policy. With respect to the optimal policy of their model, the author shows that under mild assumptions, an internally financed firm is less likely to issue dividends or to expand capacity compared with a firm with access to the perfect 
capital market.

The third paper is by Joice Hu and Ping Su on "Supply Chain Debt Financing in Competition". The paper extends the work of Brander and Lewis (1986) who show that two manufacturers who sell directly to consumers by competing Cournot behave more aggressively in the product market if they use debt financing. The extension shows that the Brander and Lewis (1986) result continues to hold for two competing supply chains.

The fourth paper is by Soraya Fatehi and Michael R. Wagner on "Crowdfunding via Revenue-Sharing Contracts". The paper formulates a new model of a crowdfunding practice recently introduced by Bolstr and Localstake. In this model, a platform acts as a matchmaker between a firm needing funds and a crowd of investors willing to provide capital. Once the firm is funded, it pays back the investors using revenue sharing contracts. The firm determines its optimal contract parameters to maximize its expected net present value, subject to investor participation constraints and platform fees. The authors show that when the crowdfunding contracts are used optimally, the likelihood of firm bankruptcy is negligible, even for highly variable cash flows.

\section{Future Research}

The field of supply chain finance has attracted practitioners from various functional areas: banks, sellers, buyers, logistics providers, e-commerce platforms, and technology platforms. Their participation creates opportunities for more integrated, innovative solutions to supply chain challenges. Those practices generate interesting topics for future research:

Innovative supply chain financing solutions: Roles of supply chain partners have changed significantly in the past decade. Parties who possess supply chain transaction data (e.g., sellers, buyers, logistics providers, platforms) have started to explore creative ways of using the information to facilitate not only the physical flows and information flows but also the financial flows within the supply chain. Technological interventions into personal and commercial finance (i.e., Fintech) present new opportunities for supply chain finance. It is important to understand 
the value proposition and rationale for any innovative supply chain financing solutions, and evaluate its impact on each individual supply chain partner as well as on the overall supply chain performance.

Financing solutions in complex supply chains: Most of the current research has focused on simple one-supplier-one-buyer supply chain. How should supply chain finance solutions take into consideration of the supply chain topology (serial, assembly, distribution, and other network systems)? How would supply chain financing solutions affect firms' marketing strategies, growth strategies, and competitive landscapes? Answers to those questions help us understand the strategic implications of supply chain finance.

Supply chain contracts: Payment terms constitute an important part of supply chain contract, and directly affect trading firms' cash-tocash cycles, which in turn affect firms' financing decisions. Supply chain finance generates new questions for supply chain contracts research to go beyond the study of prices and quantities. It is important to understand the role of contracts in coordinating the physical, information, and financial flows within the supply chain.

Empirical research: Innovation in supply chain finance would not be possible without the advancement of information technology and analytical tools, which enables the quick collection of data generated during supply chain activities, the sophisticated analysis of relevant data from all available sources, and the speedy execution of financial transactions. Yet, empirical research is scarce in the area of supply chain finance. Empirical research and theoretical models should form a virtuous cycle in supply chain finance research, within which the practical relevance of supply chain finance theory should be tested by rigorous empirical research, and phenomena identified in empirical studies pose new questions that push the frontier of supply chain theory.

Panos Kouvelis, Ling Dong and Danko Turcic Olin Business School, Washington University in St. Louis, USA 


\section{References}

Brander, J. A. and T. R. Lewis. 1986. "Oligopoly and Financial Structure: The Limited Liability Effect". The American Economic Review. 76(5): 956-970.

Global Business Intelligence. 2016. "State of Supply Chain Finance Industry: Entering a New Era of Maturity". URL: http://www . demica.com/library/gbi-2016-state-of-scf-april-21.pdf.

Herath, G. 2015. McKinsey Payments. URL: http://www.demica.com/ library/gbi-2016-state-of-scf-april-21.pdf.

Miller, M. and F. Modigliani. 1961. "Dividend Policy, Growth, and Valuation of Shares". The Journal of Business. 34(4): 411-433.

Modigliani, F. and M. Miller. 1958. "The Cost of Capital, Corporation Finance and the Theory of Investment". American Economic Review. 48(3): 261-197. 